\title{
Habitats Characteristic and the Resistance Status of Aedes sp. Larvae in the Endemic Areas of Dengue Haemorrhagic Fever in Sewon Subdistrict, Bantul Regency, Special Region of Yogyakarta
}

\author{
Soenarwan Hery Poerwanto ${ }^{1 *}$, Defriana Lutfi Chusnaifah ${ }^{1}$, Giyantolin ${ }^{1}$, Dila Hening Windyaraini ${ }^{1}$ \\ 1) Faculty of Biology, Universitas Gadjah Mada, Jl. Teknika Sel., Sekip Utara, Yogyakarta 55281, Daerah Istimewa Yogyakarta, \\ Indonesia
}

Submitted: 17 April 2020; Accepted: 28 July 2020; Published: 15 August 2020

\begin{abstract}
Dengue Hemorrhagic Fever (DHF) is caused by Dengue Virus and transmitted by female Aedes mosquito which spread almost all over the world. Aedes sp. mosquito lives cosmopolitan and breeds in wet environments. Panggungharjo and Bangunharjo villages were categorized as endemic and non-endemic DHF areas, respectively. The aims of this research were to study the characteristics of Aedes sp. mosquito breeding sites, the identity of presence species found in the sites, and the resistance status of Aedes sp. mosquitoes against organophosphate insecticide. The method was using a larval survey which consists of 200 houses as respondents located in Panggungharjo and Bangunharjo villages. The larval resistance was tested by a biochemical method since resistance could be associated with esterase enzyme activity. The characteristics of mosquito breeding sites that found were open containers, filled with clear and calm water, dark and rough wall surfaces, the bottom surface was not directly in contact with the ground, the water temperature was $27-29{ }^{\circ} \mathrm{C}, \mathrm{pH} 6.5-7$, and not directly exposed to sunlight. There was only one species of mosquito was found, Aedes aegypti. The resistance test of Aedes sp. larvae showed that Aedes sp. larvae population from Panggungharjo village were susceptible, and Aedes sp. larvae from Bangunharjo village were in moderate resistant against organophosphate insecticide.
\end{abstract}

Keywords: Aedes sp., breeding site, characteristics, resistance status

\section{INTRODUCTION}

Dengue fever or Dengue haemorrhagic Fever (DHF) is caused by the virus Flavivirus; type DENV I, II, III, and IV (Knipe \& Howley, 2007) and type I, II, and IV occur more often in Indonesia (WHO, 2009). Dengue haemorrhagic fever is spread by female mosquitoes of the genus Aedes that are scattered in the 112 tropical and subtropical countries in the world (WHO, 2013). Aedes has cosmopolitan lifestyle and easily adapt to the urban environment and the countryside. Some member species of Aedes that are often found in Indonesia is Aedes aegypti and Aedes albopictus (Suksesi \& Surahma, 2007). Aedes females generally suck blood in the

\footnotetext{
*Corresponding author

Tel.: +628164889999

Email: soenarwan@ugm.ac.id

(C) 2020, J. Tropical Biodiversity Biotechnology (CC BY-SA 4.0)
}

morning and towards evening. Adult mosquitoes can survive for two weeks and are capable of laying at least 100 eggs each spawn. The eggs of Aedes solitary, with a dark colour and can survive in dry conditions for up to 9 months and can hatch if they are in optimal conditions (Service, 1996).

The Ministry of Health of the Republic of Indonesia noted that the Hemorrhagic fever ever is an extraordinary occurrence in Indonesia. Bantul regency is an area that has regions of endemic and non-endemic infected with the Dengue Hemorrhagic Fever (DHF). According to the Department of Health (Health office) Bantul Regency, the number of DHF cases in 2015 as many as 1.441 cases, then increased to 2.442 cases in 2016. Every year DHF cases always occur, especially in Sewon sub-districts such as Panggungharjo and Bangunharjo villages which are included as urban 
environments that continues to grow and has the potential to become an endemic area of DHF (Department of Health Bantul Regency, 2016; 2017).

Responding to outbreaks or extraordinary events of dengue in several regions in Indonesia, the government, through the Health Service, has taken various steps to deal with and control the disease. Programs that are encouraged include the $3 \mathrm{M}$ Plus movement (Menguras: Drain, Menutup: Cover, and Memanfaatkan kembali: Reuse items; plus mosquito control with larvacide, plants, and fish), efforts to use insecticides through space spraying (thermal fogging / fumigation or Ultra Low Volume/ULV) with insecticides in DHF-prone areas (Widiarti et al., 2011). The use of insecticides with active ingredients organophosphate (Malathion) in the long term with high frequency for insect control causes an increase in mosquito resistance to these active compounds (Stojanovich \& Scott, 1966). Therefore, it is important to do habitat mapping, observation of breeding site characteristics, and resistance status of mosquito larvae to support the eradication and control program of infectious disease vectors, especially dengue fever/DHF.

\section{MATERIALS AND METHODS}

This research was conducted in the field and laboratory. Research was done with survey method in Panggungharjo and Bangunharjo Villages, Sewon Sub-District, Bantul Regency, Special Region of Yogyakarta, which were endemic and non-endemic areas of Dengue Fever. The survey was conducted to observe the characteristics of mosquito breeding sites and sampling larvae in one hundred (100) houses in each village. The manufacture of preparations and identification of mosquitoes and the larvae held in the Laboratory of Systematics of the Animal Section of Parasitology, Faculty of Biology, Universitas Gadjah Mada. Treatment and test status of the resistance carried out in the Laboratory of Parasitology, Faculty of Medicine, Universitas Gadjah Mada. Research conducted in March - June 2013.

\section{Observation of Habitat Characteristics and}

\section{Larva Collection}

Observations were carried out by roaming methods or surveys to places that could potentially be breeding grounds for mosquitoes, such as water puddles, tanks, buckets, open water jars, spring water sources, rivers, sewers, plantations or vacant land. Observations were made on 100 houses in each Panggungharjo and Bangunharjo Villages randomly. The houses surveyed were recorded and seen whether or not there were larvae in containers in their environment. These positive containers or breeding grounds were recorded and described that covers: basic material and habitat edges, water turbidity, and vegetation or shade. Data was used to determine the number of houses and characteristics of larva positive containers and monitor Aedes population with two indicators, namely HI (House Index) and CI (Container Index).

The calculation of House Index (HI) and Container Index (CI) (WHO, 2009).

a) House Index (HI)

$$
\begin{aligned}
& H I=\frac{\text { The number of houses positive for larvae or eggs }}{\text { The whole number of houses examined }} \times 100 \% \\
& \text { b) Container Index (CI) } \\
& C I=\frac{\text { The number of Container positive for larvae or eggs }}{\text { The whole number of Container examined }} \times 100 \%
\end{aligned}
$$

Mosquito larvae or pupae found in the location were counted and taken with a dipper or pipette to be identified. Houses with positive containers with larvae, one or two ovitrap were installed. Positive water storage environmental parameters contained larvae/pupae were observed, includes: water temperature, air temperature, and water acidity $(\mathrm{pH})$. Data from observations of types and characteristics of mosquito breeding sites and types of mosquito larvae were analyzed descriptively.

Questions were proposed to 200 residents in the villages of Panggungharjo and Bangunharjo. Data were analyzed quantitatively to compare community knowledge in the two villages.

\section{Identification of Larvae}

Larvae obtained from the field were identified in the Laboratory of Systematics of the Animal Section of Parasitology, Faculty of Biology, Universitas Gadjah Mada, with the identification book "Illustrated Key to Mosquitoes of Vietnam" by C. J. Stijanovich and H. G. Scott (1966). Mosquito larvae other than the Aedes genus were killed and discarded, while Aedes larvae were taken to test their resistance.

\section{Status of Resistance}

Larvae identified as Aedes genus were taken of three (3) individuals for each region (hamlets) in every village. One final or 3rd instar Aedes larvae were taken and homogenized with $500 \mu$ l phosphate buffer solution (PBS) pH 7.0. Each larva made two replicates for test material. The substrate was prepared with $3 \mathrm{mg} \alpha$-Naphtyl acetate dissolved in $500 \mu \mathrm{l}$ acetone and added with $50 \mathrm{ml}$ PBS solution, homogenized. Reagent coupling was made with 30 $\mathrm{mg}$ of Fast blue which was homogenized with $7 \mathrm{ml}$ of $5 \%$ SDS and $3 \mathrm{ml}$ of distilled water. The prepared homogenates were taken $50 \mu \mathrm{l}$ with a micropipette and put into a microplate well, then added with $50 \mu \mathrm{l}$ 
of the substrate, let stand for 60 seconds. A total of $50 \mu \mathrm{l}$ reagent coupling solution was added to the microplate well and let stand for 10 minutes. Color changes were observed (colorimetry). The color change reaction was stopped by adding $50 \mu \mathrm{l}$ of $10 \%$ Acetic Acid. Determination of color intensity that occurs, analyzed quantitatively by ELISA, by reading the Absorbance Value (AV) with a Microplate Reader at a wavelength of $450 \mathrm{~nm}$.

\section{Data Analysis}

Testing results data on the status of resistance were measured qualitatively and quantitatively. Qualitative measurements were carried out based on color changes (colorimetry), while quantitative resistance status measurements were based on absorbance values (AV).

The resistance status figures according to Lee (1991) are as follows:

- Vulnerable (not resistant or very vulnerable $(\mathrm{VV})): \mathrm{AV}<0.70$

- Medium resistance (moderate susceptibility (MS)): 0.70-0.90

- High resistance (not vulnerable (NV)): AV > 0.90
Control of substrate or medium was used as a comparison of the treatment or method used.

\section{RESULTS AND DISCUSSION}

Data collection of mosquito larvae were conducted from each village in 3 (three) hamlets. The village of Panggungharjo represented hamlets: Garon, Geneng, and Krapyak Wetan. The village of Bangunharjo represented hamlets: Tarudan, Wojo, and Jotawang. At all points of data retrieval, larvae of Aedes were found. The village location selection was based on 2012 annual larvae monitoring data and a history of fogging/fumigation treatments at the research location. The sixth data retrieval location had $60-70 \%$ free larvae and was recommended by the officers of the local health center as a location prone to mosquito breeding.

Observation of Habitat Characteristics and Larva Collection

The results of the data collection on mosquito larvae in Panggungharjo village showed that in Garon, Geneng, and Krapyak Wetan Aedes mosquito larvae were positive. In Garon hamlet, there were 8 houses positive for mosquito larvae in 8 baths. In Geneng

Table 1. Types of mosquito larvae habitat found in Panggungharjo Village.

\begin{tabular}{|c|c|c|c|c|c|}
\hline No. & Hamlets & Habitat/Container & Total & Larva Found & $\begin{array}{c}\text { The Number of } \\
\text { Larvae }\end{array}$ \\
\hline \multirow[t]{10}{*}{1.} & Garon & Bath & 8 & Aedes aegypti & +++ \\
\hline & & Bath in Water Closet & - & - & - \\
\hline & & Water tank & - & - & - \\
\hline & & Bucket & - & - & - \\
\hline & & Used tires & - & - & - \\
\hline & & Flower pot & - & - & - \\
\hline & & Bird cage & - & - & - \\
\hline & & Pool & - & - & - \\
\hline & & Clay Water Vessel & - & - & - \\
\hline & & Cans/garbage & - & - & - \\
\hline \multirow[t]{9}{*}{2.} & Geneng & Bath & 3 & Aedes aegypti & ++++ \\
\hline & & Bath in Water Closet & 1 & Aedes aegypti & ++++ \\
\hline & & Water tank & - & - & - \\
\hline & & Bucket & - & - & - \\
\hline & & Flower pot & - & - & - \\
\hline & & Bird cage & - & - & - \\
\hline & & Pool & - & - & - \\
\hline & & Clay Water Vessel & - & - & - \\
\hline & & Cans/garbage & - & - & - \\
\hline \multirow[t]{5}{*}{3.} & Krapyak Wetan & Bath & 3 & Aedes aegypti & +++ \\
\hline & & Bath in Water Closet & 2 & Aedes aegypti & +++ \\
\hline & & Water tank & - & - & - \\
\hline & & Bucket & - & - & - \\
\hline & & Cans/garbage & - & - & - \\
\hline
\end{tabular}

Description of the number of larvae:

$+\quad: 1-10 \quad+++\quad: 21-30$

$++: 11-20 \quad++++\quad:>30$ 

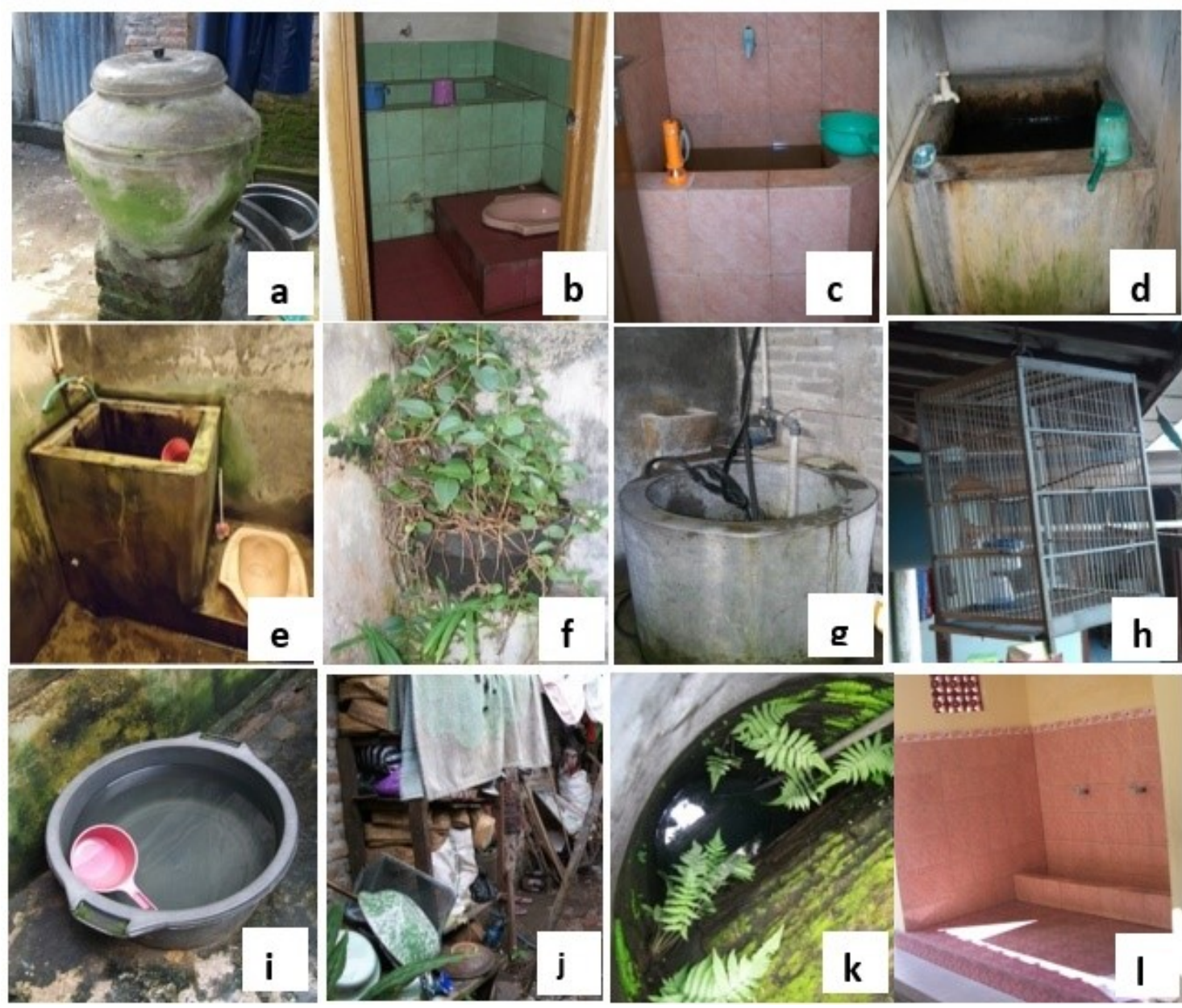

Figure 1. Types of containers that could potentially become a breeding ground for Aedes in Garon, Geneng, and Krapyak Wetan hamlets, Panggungharjo Village. Description: a. Clay Water Vessel; b. Bath in Water Closet ceramic; c. Bath ceramic; d. Bath cement; e. Bath in water closet cement; f. Potted plants; g. Open wells; h. Bird cages; i. Bucket/ reservoir open water; j. Garbage and a crock; k. pool; l. The place of ablution.

hamlet, there were 4 houses positive for larvae in 3 baths and 1 tub of water closet. In Krapyak Wetan hamlet, there were 5 positive houses contained the larvae of Aedes in 3 baths of water closet and 2 baths (Table 1).

Types of containers with a positive sign were ceramic bathtub, bathtub cement, and bath in a water closet (Table 1). Ceramic bathtubs with positive mosquito larvae are in public facilities such as mosques and residential houses (Figure 1). Generally, there are deposits of dirt or sand at the base of the water or the crust. Bath cement with positive larvae was found in citizens home (Figure 1). Bath in a water closet with positive larvae contained in the residents ' houses and used cement tub (Figure 1e).

From interviews with residents, it was known that the dengue fever case in Panggungharjo Village at the beginning of this year had experienced an increase. Garon Hamlet has 3 cases, Geneng Hamlet has 4 cases, and in Krapyak Wetan Hamlet has 5 cases. In 2012 there were only 9 cases recorded at the Sewon Health Center 2.

The results of larvae data collection in
Bangunharjo Village showed that Wojo, Jotawang, and Tarudan hamlets were positive for Aedes larvae. In Tarudan hamlet, there were 4 houses with positive mosquito larvae in 3 baths and 1 well. In Wojo hamlet, there were 8 houses positive for larvae in 8 baths. In Jotawang hamlet, there were positive larvae Aedes in in 1 bath (Table 2).

Containers observed for positive of mosquito larvae were bathtubs generally located in a house with a tub of cement or ceramic (Figure 2) and open wells inside the house (Figure 2) (Table 2). The habitats observed and positive for larvae of Aedes were mostly in baths.

Bangunharjo Village is a village with a nonendemic status of dengue fever cases in 2012, as dengue fever tends not to be continuous every year. However, it could potentially become an endemic area considering its located in the border of the city and is directly adjacent to Panggungharjo Village which is an endemic area of dengue Fever. In addition, low numbers of free larvae of Aedes in Bangunharjo village increase the potential spread of dengue fever. Bangunharjo village has a distribution region, which tend to cluster and are divided into 
Table 2. Types of mosquito larvae habitats found in Bangunharjo Village.

\begin{tabular}{|c|c|c|c|c|c|}
\hline No. & Hamlet & Habitat/Container & Total & Larva Found & $\begin{array}{c}\text { The Number of } \\
\text { Larvae }\end{array}$ \\
\hline & \multirow[t]{9}{*}{ Tarudan } & Bath & 3 & Aedes aegypti & +++ \\
\hline & & Bath in Water Closet & - & - & - \\
\hline & & Well & 1 & Aedes aegypti & ++++ \\
\hline & & Bucket & - & - & - \\
\hline & & Water tank & - & - & - \\
\hline & & used tires & - & - & - \\
\hline & & Clay Water Vessel & - & - & - \\
\hline & & Flower pot & - & - & - \\
\hline & & Others & - & - & - \\
\hline & \multirow[t]{8}{*}{ Wojo } & Bath & 8 & Aedes aegypti & +++ \\
\hline & & Bath in Water Closet & - & - & - \\
\hline & & Well & - & - & - \\
\hline & & Bucket & - & - & - \\
\hline & & Water tank & - & - & - \\
\hline & & used tires & - & - & - \\
\hline & & Flower pot & - & - & - \\
\hline & & Others & - & - & - \\
\hline & \multirow[t]{9}{*}{ Jotawang } & Bath & 1 & Aedes aegypti & ++ \\
\hline & & Bath in Water Closet & - & - & - \\
\hline & & Well & - & - & - \\
\hline & & Bucket & - & - & - \\
\hline & & Water tank & - & - & - \\
\hline & & used tires & - & - & - \\
\hline & & Clay Water Vessel & - & - & - \\
\hline & & Flower pot & - & - & - \\
\hline & & Others & - & - & - \\
\hline
\end{tabular}

Description of the number of larvae:

+ :1-10 $\quad+++: 21-30$

$++: 11-20 \quad++++:>30$

several complexes that are separated by rice fields. From the results of interviews with residents, there was an outbreak of dengue fever at the beginning of 2013. In Jotawang, Wojo, and Tarudan hamlets, each has two cases of dengue fever.

In Wojo Hamlet in 2013, a chikungunya outbreak was also spread by Aedes mosquitoes. Therefore, in March, fogging/fumigation was carried out. During the research period, which was in May 2013 in Jotawang, fogging/fumigation was also held, but Aedes larvae and eggs were still found in one of the resident's house. This situation shows that fogging is less effective.

Based on the results above, habitat characteristics of the Aedes is a container containing clean water, water with clear to slightly turbid, quiet, with rough walls, well-lit/with shade, and the base of the water is not in direct contact with the ground. In addition, used tires and used goods in the vicinity of the source of water were found in the Bangunharjo Village. These items could potentially become a breeding ground for Aedes.

The majority Habitat of Aedes found in both villages were baths in the house or closed baths. In this case, it is defined as the location/venue for the whole activity or the majority of mosquito life cycle. Including mating and laying eggs.

On Garon Hamlets, one container was found positive for larvae but has murky water and almost translucent. Such circumstances were also found in the Wojo Hamlets. Turbidity of water is related to the difference in the structure of the soil and water management in such environments that cause cloudy water or leave the crust is colored yellow or black. The content of dissolved substances and water turbidity limits the ability of light to penetrate water and can be used effects of aquatic biota. However, the discovery of the larvae of Aedes showed that it can adapt in an environment that is not beneficial.

Environmental parameters review of Aedes larvae habitats in the Panggungharjo Village, i.e. an average water temperature $28^{\circ} \mathrm{C}$, air temperature of $33.67{ }^{\circ} \mathrm{C}$, and water $\mathrm{pH}$ of 6.8. While in Bangunharjo Village, the average water temperature was $28.13{ }^{\circ} \mathrm{C}$, air temperature of $33.67^{\circ} \mathrm{C}$, and water $\mathrm{pH}$ of 6.8. The environmental conditions of the container with positive larvae in both villages tended to be the same or close to and within the normal 


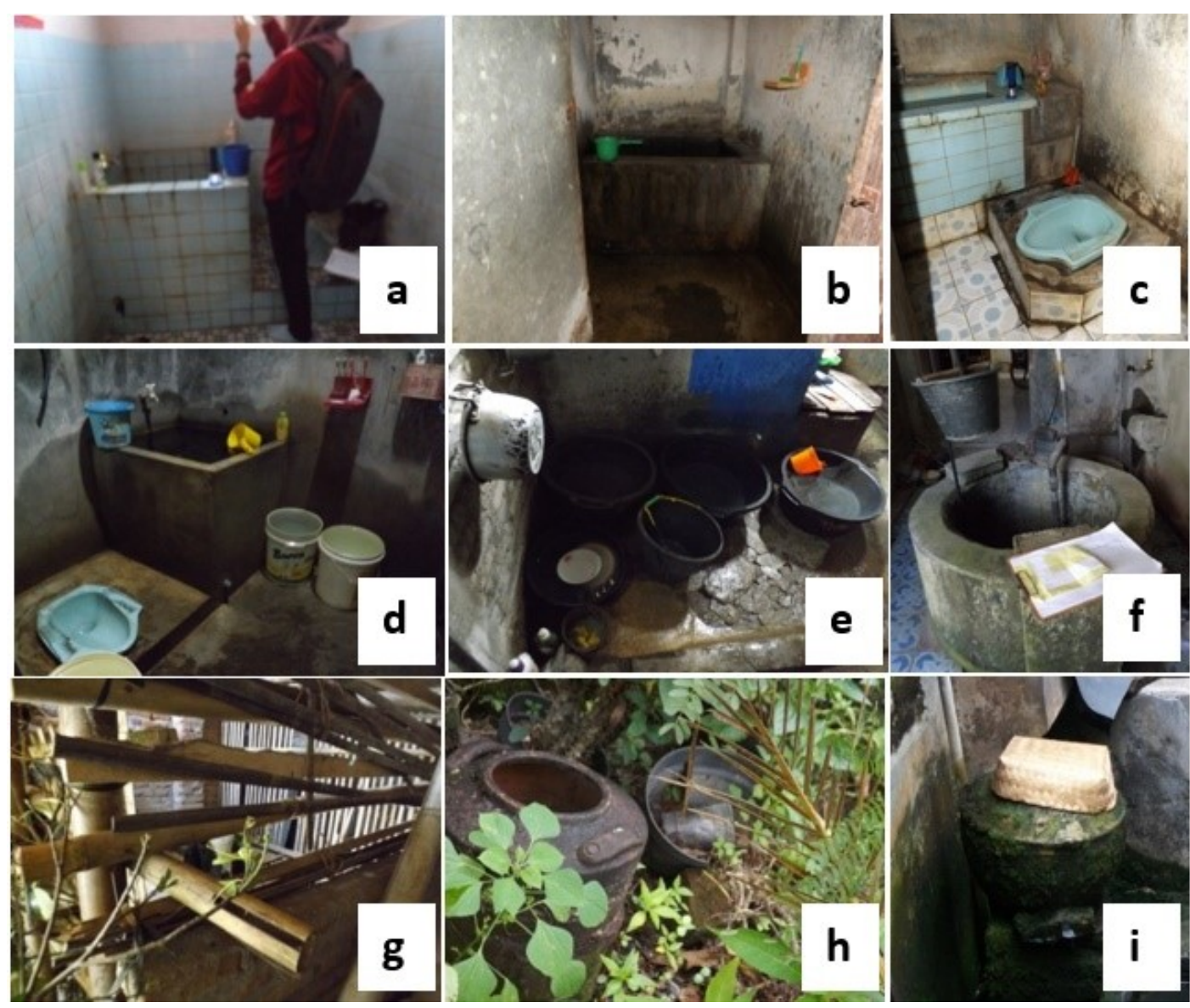

Figure 2. Types of containers that could potentially be the habitat of Aedes in Tarudan, Wojo, and Jotawang hamlets, Bangunharjo Village. Description: a. Bath Ceramic; b. Bath cement; c. Bath in Water Closet ceramic; d. Bath in Water Closet cement; e. Bucket; f. Open wells; g. The enclosure of livestock; h. Pot plants; i. Clay Water Vessel.

range. The difference in air temperature was due to fluctuations in the weather at the time of data collection. The temperature of the air tends to heat into warm water temperature make the development of mosquitoes eggs, larvae, and pupae faster.

The water temperature still in the optimum temperature range becomes the breeding places and larval development of Aedes. Aedes larvae are capable of developing optimum at a water temperature of 25 $-30{ }^{\circ} \mathrm{C}$. Tolerance and range of the optimum temperature depend on the type/species of mosquito and its adaptation. They also capable of growing optimally at a $\mathrm{pH}$ of 4.4 to 9.3 , and the conditions in the second study site were at the optimal pH. Environmental conditions are supported by the temperature of the air for it tends to be warm in the dry season, so Aedes mosquitoes can complete the whole stage of its life cycle more quickly.

In terms of the HI and the CI (Table 3), it is known that Panggungharjo and Bangunharjo villages have the potential of prone to cases of Yellow fever. In Garon, Krapyak Wetan, as well as Wojo hamlets, they potentially have the emergence of DHF cases given the high HI. Although the value of CI tends to be low or below 10\%, the potential spread of Yellow fever disease remains high given the presence of the vector in the form of Aedes mosquito. Therefore, it is worth the effort to seriously addressing and combating infectious disease vectors, in this case mosquitoes.

At the beginning of 2013, an outbreak of Chikungunya occurred in Wojo hamlet. This was followed by fogging. Panggungharjo village, which was a high endemic area in 2012, the value of CI in the three villages observed had relatively low or less than 10\% (Table 3). The value of HI in two hamlets, namely Garon and Krapyak Wetan were relatively high of $26.67 \%$ and $16.67 \%$. Although the value of HI was relatively high, in 2012-2013 Panggungharjo village did not experience outbreaks of diseases transmitted through vector, but from year to year the number of dengue fever/DHF sufferer or who are experiencing symptoms of dengue fever/DHF continued to increase.

The success of government programs in control and eradication of infectious disease vectors can be known through citizen's level of knowledge of about the dengue fever (DHF). Recap results of 200 respondents consisted of 100 residents of Panggungharjo Village and 100 citizens of Bangunharjo Village knew that the knowledge of 
Table 3. The value of House Index (HI) and Container Index (CI) in Panggungharjo and Bangunharjo villages.

\begin{tabular}{clcccccc}
\hline Village & Hamlets & $\begin{array}{c}\text { House } \\
\text { Checked }\end{array}$ & $\begin{array}{c}\text { House } \\
\text { Positive } \\
\text { Larvae }\end{array}$ & $\begin{array}{c}\text { HI } \\
\mathbf{( \% )}\end{array}$ & $\begin{array}{c}\text { Containers Are } \\
\text { Inspected }\end{array}$ & $\begin{array}{c}\text { Containers } \\
\text { Positive For } \\
\text { Larvae }\end{array}$ & CI (\%) \\
\hline \multirow{3}{*}{ Panggungharjo } & Garon & 30 & 8 & 26.67 & 113 & 8 & 7.08 \\
& Geneng & 40 & 4 & 10 & 104 & 4 & 3.85 \\
& Krapyak Wetan & 30 & 5 & 16.67 & 97 & 5 & 5.15 \\
\hline \multirow{3}{*}{ Bangunharjo } & SUBTOTAL & $\mathbf{1 0 0}$ & $\mathbf{1 7}$ & $\mathbf{1 7}$ & $\mathbf{3 1 4}$ & $\mathbf{1 7}$ & $\mathbf{5 . 4 1}$ \\
\hline & Tarudan & 32 & 4 & 12.50 & 102 & 4 & 3.92 \\
& Wojo & 31 & 8 & 25.81 & 101 & 8 & 7.92 \\
& Jotawang & 37 & 1 & 2.70 & 102 & 1 & 0.98 \\
\hline & SUBTOTAL & $\mathbf{1 0 0}$ & $\mathbf{1 3}$ & $\mathbf{1 3}$ & $\mathbf{3 0 5}$ & $\mathbf{1 3}$ & $\mathbf{4 3}$ \\
\hline \multirow{2}{*}{ TOTAL } & $\mathbf{2 0 0}$ & $\mathbf{3 0}$ & $\mathbf{1 5}$ & $\mathbf{6 1 9}$ & $\mathbf{3 0}$ & $\mathbf{4}$ \\
\hline
\end{tabular}

Panggungharjo society about DHF, its causes, as well as the eradication of mosquito nests was higher compared to the citizens of Bangunharjo.

Bangunharjo Village residents knew that dengue fever/DHF and its rising symptoms are equal to $(80 \%)$, but they who didn't knew the cause reach $(40 \%)$ and its disease vector to $(44 \%)$ about the dengue fever/DHF. However, community awareness of cleanliness is quite high up to $(74 \%)$. Another case with Panggungharjo Village community, out of 100 respondents, 95 respondents had knowledge of dengue fever disease. Knowledge about the causes and carriers of dengue fever disease were $(90 \%)$ and understanding of family hygiene and health were $(100 \%)$. This is reinforced by the public's awareness to use the biological method (fish) as an effort to control mosquito vectors compared to using abates or other chemicals.

However, the intensification of extension program by the government to the community, especially in endemic regions should be improved. Because the value of $\mathrm{HI}$ in Panggungharjo and Bangunharjo villages still relatively high. These circumstances need to be the highest attention of the government in dealing with outbreaks of infectious diseases through vectors in Panggungharjo and Bangunharjo villages, such as through the improvement of human resources, environmental cleanliness, and with the extermination of vector directly.

\section{The Identification of Larvae}

The larvae obtained from the 30 containers positive for the larvae were Aedes aegypti larvae (Figure 3). They were found in all containers of positive larvae with the amount varies from little (10-20 tails) to very many $(>>100)$. Aedes larvae identified from its activities which is able to dive at the base of the old containers. Aedes larvae found in large quantities in containers made of cement or with a rough surface, even found in open wells in Tarudan Hamlet.

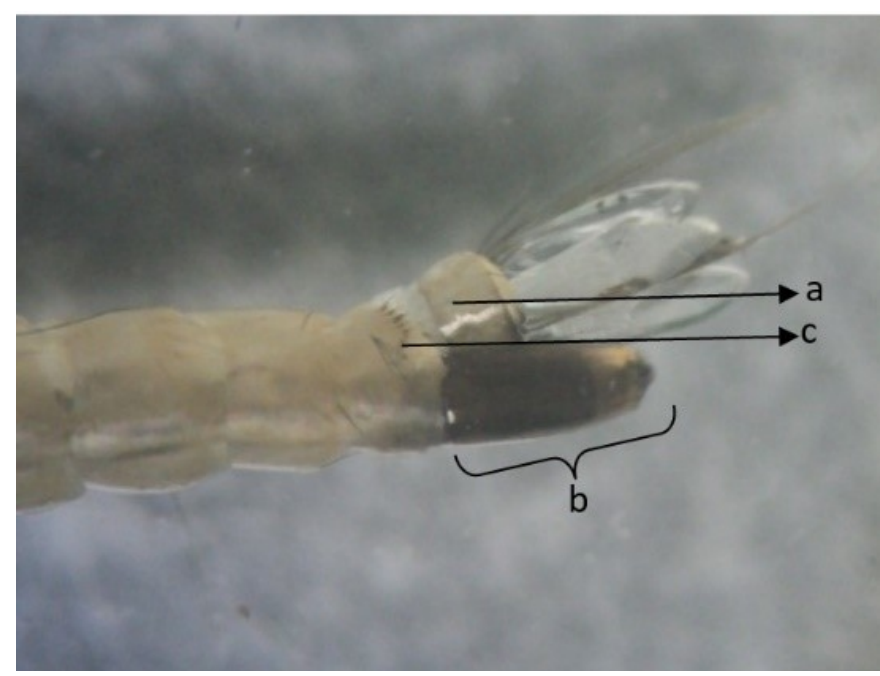

Figure 3. The larvae of Aedes aegypti magnification 4x100. Description: a. Saddle; b. Siphon; c. Sex comb.

Aedes aegypti larvae can be identified from the presence of the siphon, it is a self-contained breathing apparatus in the larvae of the Culicidae members with length tend to be the same with the saddle. The saddle is a thickening or sclerotized caudal part contained mobility aids on mosquito larvae, namely tracheal gill and the caudal seta/anal brush (Figure 3a). On Aedes larvae, the saddle is only partially experienced thickening. On Aedes aegypti larvae posterior parts there are two rows of sex comb whereas in Aedes albopictus, there is only one line. Sex comb of the posterior/the second line on the larvae of Aedes aegypti have a thorn on the side (Figure 3c).

The identification can be simply observed by 
looking at the posterior or last segment on mosquito larvae. Obtained Aedes larvae have a siphon (Figure $3 \mathrm{~b})$ with medium size and length which is relatively the same with the saddle. Saddle experienced a thickening or sclerotized most and there are two lines of sex comb with the second line branching and barbed side (Figure 3c).

\section{Status of Resistance}

Resistance Status of Aedes larvae in Panggungharjo and Bangunharjo Villages against organophosphate compounds tested by the method of Elisa Assay based on the value of the Absorbance Value (AV) using ELISA reader. Testing with biochemical methods was conducted to determine the activity of the enzyme esterase non-specific with regard to the mechanism of the resistance onset, namely the onset of the allele for resistance in populations (Macoris et al., 2003). The results of research analysis were done by 2 ways, namely qualitative and quantitative analysis. Qualitative analysis was done by comparing the intensity of sample color with the positive control and negative. Quantitative analysis was done by reading the absorbance value (AV) using ELISA reader at $\lambda=450 \mathrm{~nm}$. To determine the Resistance Status of mosquito larvae the standard used was Lee (1991) (Lee, 1991).

Based on Table 4 can be seen that Aedes larvae in the Village of Panggungharjo has average status of Susceptible (SS) with the mean AV $0.539 \pm 0.083$. The general condition indicates that control of the spread of dengue fever in Panggungharjo Village with insecticides organophosphates can still be done with a dose that is generally applied. However, the potential change of the Susceptible (VV) Resistant Medium (MS) to watch over the treatment and use of insecticides, especially of insecticides with the active ingredients of organophosphate, on a continuous basis. In general, the difference AV in the three villages shows that the activity of the control and eradication of infectious disease vectors has been done yet cause effects that lead to active resistance mechanisms of mosquitoes especially Aedes against insecticide type of organophosphate.

Larvae of Bangunharjo Village have an average AV $0.777 \pm 0.150$ status Resistant Medium (MS) (Table 5). The Tarudan hamlet has AV which is the highest $0.848 \pm 0.130$. Mosquito larvae in the three hamlets in Bangunharjo village have a higher potential to be Resistant to High (NV) given the absence of a treatment-spraying/fogging which took place on two consecutive years. In 2012, Bangunharjo Village has the fumigation in the three hamlets observed related cases of Chikungunya and at the beginning of 2013, in Tarudan, Wojo, and Jotawang hamlets has also carried out spraying. However, there are still adult mosquitoes can survive and lay eggs in the ovitrap installed. It shows that fogging has been done less effectively, for there began to be resistance that resulted in the mosquito life cycle is not interrupted and the possibility of the spread of infectious disease through mosquito vector is high.

Fogging had been carried out for approximately two months prior to the study. It was done related to the outbreak of Chikungunya in the region. Insecticides were often used for fogging in Panggungharjo and Bangunharjo villages were a type of Malathion made active organophosphate with a target of adult mosquitoes. For the eradication of mosquito larvae, citizens/ordinary people use tilapia as a biological control and chemical use of Temefos or abate.

The resistance nature of mosquitoes to an insecticide was caused by the presence of genetic aspects with the R-genes (Mulyaningsih, 2004).

Table 4. Resistance Status of Larvae Aedes of Panggungharjo Village.

\begin{tabular}{clccc}
\hline No. & Sample (Hamlets) & Absorbance Value (AV) & Resistance Status & $\begin{array}{c}\text { Average } \\
\text { (AV) }\end{array}$ \\
\hline 1 & Garon & $0.601 \pm 0.113$ & susceptible (VV) & $\mathbf{0 . 5 3 9 \pm 0 . 0 8 3}$ \\
2 & Geneng & $0.499 \pm 0.038$ & susceptible (VV) & Susceptible (VV) \\
3 & Krapyak Wetan & $0.517 \pm 0.044$ & susceptible (VV) & \\
4 & Substate / medium & $0.383 \pm 0.025$ & susceptible (VV) & \\
\hline
\end{tabular}

Table 5. Resistance Status of Larvae Aedes of Bangunharjo Village.

\begin{tabular}{clccc}
\hline No. & Sample (Hamlets) & Absorbance Value (AV) & Resistance Status & $\begin{array}{c}\text { Average } \\
\text { (AV) }\end{array}$ \\
\hline 1 & Tarudan & $0.848 \pm 0.130$ & Resistant Medium (MS) & $\mathbf{0 . 7 7 7} \pm \mathbf{0 . 1 5 0}$ \\
2 & Wojo & $0.718 \pm 0.167$ & Resistant Medium (MS) & Resistant \\
3 & Jotawang & $0.767 \pm 0.146$ & Resistant Medium (MS) & Medium (MS) \\
4 & Substate / medium & $0.383 \pm 0.025$ & susceptible (VV) & \\
\hline
\end{tabular}


Genetics aspects influence on the physiological system of the mosquito, includes affecting the work of enzymes esterase that is able to neutralize the insecticides, especially the type of organophosphate. Other aspects such as mobilization, adaptation and regeneration of the mosquito broad quickly also affect the ability of the mosquito in spreading the disease without being affected by the insecticide.

Resistant mosquitoes have the potential to pass down their resistant genes to their offspring, as well as mosquitoes with medium resistance status. Vulnerable mosquitoes have the potential to become medium resistant and then become resistant due to the use of the same type of insecticide for the control of DHF vectors in a long time. Seeing the increasing trend of resistance that occurs in Panggungharjo and Bangunharjo Villages, there needs to be more serious handling from the government in terms of eradicating vectors, especially mosquitoes. This is to anticipate the increasing number of resistant mosquitoes. The higher the level of resistance of the mosquito, the more difficult to control, where in addition to the dosage should be increased and should be sought new insecticide to eradicate the mosquitoes that have been resistant to such.

The ability of resistance in mosquitoes to the active compound organophosphates leads to the mechanism of nerve impulses inhibition to not occur. This is due to the physiological basis of mosquito which has enzymes esterase capable of degrading such active compounds. Enzymes esterase such as malathion carboxylesterase, oxidases or glutathione S-transferase (GST) are enzyme that can detoxify to the insecticidal ester type, in this case the organophosphorus (Macoris et al., 2003; Pimsamam et al., 2009).

\section{CONCLUSION}

The habitats characteristics of mosquitoes, in general, are open containers with long time-stagnant water, crystal clear water, and calm, with surface of rough and dark walls, while surface of the base are not directly related to the soil, the water temperature ranged between $25^{\circ} \mathrm{C}-29^{\circ} \mathrm{C}$ and $\mathrm{pH}$ of the water ranged between $6-8$, and also not exposed to direct sunlight. The type of mosquito that is found in Panggungharjo and Bangunharjo villages, Sewon District, Bantul Regency, Special Region of Yogyakarta is Aedes aegypti. Resistance Status of larvae Aedes in Panggungharjo village is Susceptible (SS) against organophosphorus compounds, while the resistance status of larvae Aedes at Bangunharjo is a Resistant Medium (RS) against organophosphorus compounds.

\section{ACKNOWLEDGMENTS}

Thank you to Mrs. Dr. Dra. Rr. Upiek Ngesti W. A., DAP\&E, M. Biomed for their guidance and input during the research and creation of research reports.

\section{REFERENCES}

Department of Health Bantul Regency, 2016, Profil of Health Bantul Regency, [Dinas Kesehatan Kabupaten Bantul], Special Region of Yogyakarta.

Department of Health Bantul Regency, 2017, Profil of Health Bantul Regency, [Dinas Kesehatan Kabupaten Bantul], Special Region of Yogyakarta.

Knipe, D. M., and Howley, P. M., 2007, Fields Virology: Flaviviridae "The Viruses and Their Replication", 5th Edition, Lippincott-Raven Publishers, Philadelphia.

Lee, H. L., 1991, Esterace Activity and Temephos Susceptibility in Aedes aegypti (L.) Larvae, Mosq. Borne Dis. Bull, Pp. 8, 91-94.

Lidia, Kartini dan Widyaningrum, E. 2008, Deteksi Dini Resistensi Nyamuk Aedes albopictus Terhadap Insektisida Organofosfat di Daerah Endemis Demam Berdarah Dengue Di Palu (Sulawesi Tengah) [Early Detection of Aedes albopictus Mosquito Resistance to Organophosphate Insecticides in Endemic Dengue Fever Areas in Palu (Central Sulawesi)], Media Kesehatan Masyarakat, 3, 2 pp. 1-6.

Macoris., Maria de, L. G., Andrighetti, Maria, T. M., L. Takaku, C. M. Glasser, Garbeloto, V. C., Bracco, J. E., 2003, Resistance of Aedes aegypti from the State of São Paulo, Brazil, to Organophosphates Insecticides. Mem Inst Oswaldo Cruq. 98(5), pp. 703-708

Mulyaningsih, B., 2004, Variation in Susceptibility Status of Organophospate Insecticide Among Several Geographic Population of Aedes albopictus Skuse in Indonesia. Berkala Ilmu Kedokteran, 36, 2.

Pimsamarn, S., Sornpeng, W., Akksilp, P., Paeporn, and Limpawitthayakul, M., 2009, Detection of insecticide resistance in Aedes aegypti to organophosphate and synthetic pyrethroid compounds in the north-east of Thailand. Dengue Bulletin. Vol. 3 Pp. 194-200.

Service, M. W., 1996, Medical Entomology for Students, London Chapman and Hall, London.

Stojanovich, C. J. and Scott, H. G. 1966. Illustrated key to mosquitoes of Vietnam, U.S.Communicable Disease Center, Atlanta. 
Sukesi, T. W. dan Surahma, A. M., 2007, Kerentanan Nyamuk Aedes aegypti L. Terhadap Senyawa Organofosfat temephos dan Malathion di Kelurahan Wirobrajan Kecamatan Wirobrajan, Yogyakarta [Vulnerability Against Aedes aegypti L. temephos and Malathion Organophosphate compounds in the Village Wirobrajan Wirobrajan subdistrict, Yogyakarta], Kesehatan Masyarakat 1,1. pp. 21, $22-25$.

Widiarti, Heriyanto, B., Boewono, D. T., Mujiono, U. W., Lasmiati and Yuliadi, 2011, Peta Resistensi Vektor Demam Berdarah Dengue Aedes aegypti Terhadap Insektisida Kelompok Organofosfat, Karbamat, dan Pyrethroid di Provinsi Jawa Tengah dan Daerah Istimewa Yogyakarta [Resistance map Dengue vector Aedes aegypti Group Against Organophosphate insecticides, carbamates, and pyrethroids in Central Java and Yogyakarta]. Buletin Penelitian Kesehatan, 39, 4. pp. 176-189.
World Health Organization (WHO), 2009, Dengue: guidelines for diagnosis, treatment, prevention and control - New edition, WHO Press, Switzerland.

World Health Organization (WHO), 2012, Monitoring and evaluation indicators for integrated vector management, WHO Press, Switzerland. 